\title{
TADALURING MICROTEACHING: AN EFFECTIVE LEARNING MODEL TO DEVELOP BASIC TEACHING SKILLS
}

\author{
Arifmiboy \\ Bukittinggi State Islamic Institute (IAIN Bukittinggi), Indonesia \\ Email: arifmiboy@yahoo.co.id
}

\begin{abstract}
This study explored the effect of using a Tadaluring microteaching learning model on mastering a number of basic teaching skills by prospective teachers. The Tadaluring microteaching learning model is a learning model which combines three forms of integrated training namely classroom practices, online practices, and offline practices. This study was classified as a quasi-experimental study with a non equivalent control group design. The sample was selected with a purpose-sampling technique. The data were analyzed using a t-test method. The results of the study were: (1) there is a significant effect of using a Tadaluring microteaching learning model on prospective teachers' basic teaching skills, (2) the average ability to master basic teaching skills of prospective teachers using the Tadaluring model was higher than 80 with a very effective interpretation used in microteaching learning.
\end{abstract}

Keywords: microteaching, online, offline, tadaluring

\section{INTRODUCTION}

Allen \& Ryan in Lakshmi [1] explicated that microteaching becomes as a scaled down teaching encounter in term of class size, lesson, length and teaching complexity. Allen \& Eve [2] pointed out that microteaching as a system of controlled practice makes it possible to concentrate on specific teaching skills and to practice teaching under controlled conditions. Singh [3] stated that microteaching is a training technique which requires prospective teachers to teach a single concept, using specified teaching skills to a small number of pupils in a short period of time. Moerdianto [4] explained that microteaching learning is directed at the formation of competencies based on the Government Regulation Number 19 of 2005 concerning on National Education Standards, in which Chapter VI article 3 contains that teacher competencies include: (1) pedagogical competence, (2) personality competence, (3) professional competence, and (4) social competence.
The effectiveness of microteaching learning using a conventional model is still low, shown by the result of a survey of 30 teachers who tutored students in training schools who concluded that from the four competencies, pedagogic competence obtained the lowest average score of 67.54 [5]. Following this, the writer visualized the result of the survey on the mastery of four teacher competencies by teaching practicum students according to the perception of the tutor teacher presented in Table 1.

In response to this, one of the efforts to improve the effectiveness of microteaching learning is to apply the Tadaluring microteaching learning model. Arifmiboy [6] stated that the Tadaluring microteaching learning model combines three forms of integrated training or practice, namely classroom practice, online practice, and offline practice. Tadaluring is an acronym for face to face inside and outside the network. The Tadaluring learning model was developed based on behavioristic learning theory, social learning theory, constructivist learning 
theory, communication theory and webbased learning design theory.

Table 1. The Students' Mastery of Teaching Basic Competencies in IAIN Bukittinggi

\begin{tabular}{lcc}
\hline \multicolumn{1}{c}{ Competencies } & Mean & Interpretation \\
\hline Pedagogical Competency & 67.54 & Fair \\
Professional Competency & 80.50 & Good \\
Personality Competency & 85.65 & Very Good \\
Social Competency & 84.30 & Good \\
\hline
\end{tabular}

Tadaluring microteaching learning model has three stages namely classroom, online and offline practices [6]. Teaching activities in the classroom are attended by supervisors and trainees in microteaching learning. The steps in classroom teaching practice including planning, teaching, giving feedback and reflection. Online practice is a practical activity carried out online with the help of communication facilities and infrastructure over the internet. Skype, for example, allows supervisor and all participants to interact with each other at the same time and in different places. Meanwhile, offline teaching practice is carried out independently by involving several students or colleagues as a media for initiating. It emphasizes efforts to maximize the opportunity to practice. Each participant records his training activities independently, both basic and integrated teaching exercises, on a partial basis.

Brown [7] defined this teaching skills as a set of related teaching behaviours that are intended to facilitate pupil learning directly or indirectly. While Passi [8] described it as a

group of teaching acts intended to facilitate pupil learning directly or indirectly. Merrill in Lakshmi [1] explained that teaching skills are instructional interactions the teacher exhibits as a display device. Allen \& Riyan [9] explained that teaching skills were generally classified into 14 skills, namely:
(1) stimulus variation, (2) set induction, (3) closure, (4) silence and nonverbal cues, (5) reinforcement of student participation, (6) fluency in asking question, (7) probing question, (8) higher-order question, (9) guest divergence, (10) recognizing attending behaviour, (11) illustrating and use of example, (12) lecturing, (13) planned repetition, and (14) completeness of communication.

In the other hand, Pasi [8] identified teaching skills as follows: (1) writing instructional objectives, (2) introducing lesson, (3) using black board, (4) selecting content, (5) select audio-visual aids, (6) recognizing attending behaviour, (6) increasing pupil participation, (7) silence and non-verbal cues, (8) fluency in questioning, (9) probing questioning, (10) explaining, (11) illustrating with examples, (12) reinforcement, (13) remedial measure, (14) giving assignments, (15) evaluation, and (16) achieving closure. Singh [10] also identified 9 types of teaching skills, namely: (1) stimulus variation, (2) reinforcement, (3) reacting, (4) quality of questioning, (5) probing questioning, (6) silence nonverbal cue, (7) explaining, (8) liveliness, and (9) recognizing and achieving attending behavior. The Tadaluring microteaching learning model was developed and applied in this study with the aim of increasing the effectiveness of mastering these various basic teaching skills.

\section{METHOD}

This study was quasi-experimental with a nonequivalence control group design. The samples were determined using a purposive sampling technique resulted in a total of 24 prospective teachers in IAIN Bukittinggi. Data were collected through 
observational tests equipped with rubric assessment, then analyzed using the $t_{\text {-test }}$.

\section{RESULTS AND DISCUSSION}

Data from the measurement of the mastery of various basic teaching skills through observational test instruments from 24 students that were divided into two groups could be presented in Table 2. Table 2 presents that the post-test value of the two sample groups could be concluded as follows: Group 1 had the average value of 81.11 with a standard deviation of 2.55 and a variant of 6.51 while for Group 2, the average value was 80.55 with a standard deviation of 1.20 and a variant of 1.43. Group 1 obtained 14.10 while Group 2 obtained 13.08. This showed that the Tadaluring microteaching learning model had a significant and consistent impact.

Table 2. Comparison of the Values of Basic Teaching Skills

\begin{tabular}{lllc}
\multicolumn{3}{c}{ Skills } & \\
\multirow{2}{*}{ Group } & \multicolumn{2}{c}{ Score } & \multirow{2}{*}{ Gain Score } \\
\hline \multirow{3}{*}{ Proup 1 } & $\mu=67.01$ & $\mu=81.11$ & \\
& $\mathrm{~S}=3.39$ & $\mathrm{~s}=2.55$ & 14.10 \\
& $\sigma=11.48$ & $\sigma=6.51$ & \\
Group 2 & $\mu=66.47$ & $\mu=80.55$ & \\
& $\mathrm{~S}=1.82$ & $\mathrm{~S}=1.20$ & 13.08 \\
& $\sigma=3.30$ & $\sigma=1.43$ & \\
\hline
\end{tabular}

The result of the first hypothesis testing showed a significant difference between the pre-test and post-test scores in the first class. The two different test results were averaged by $t_{\text {-test }}$. Paired sample $t_{\text {-test }}$ generated Sig. 0.001, smaller than alpha 0.05 , thus the data proved to have a significant relationship. In the paired sample $\mathrm{t}_{\text {-test }}$ output, the $t$ count value is 26.227 while $t$ table is 2.201 . Thus the value of $t$. count is higher than $t$ table (26.227> 2.201) then the data generated different average. While the Sig. obtained was 0.000 , smaller than alpha (0.05), it could be concluded that there were significant differences between the average pre-test and post-test in Group 1.

Testing of the second hypothesis, with respect to the difference between the average value of the pre-test and post-test in the second group, showed the results of the test using paired sample $t_{\text {-test }} \mathrm{t}$ obtained the value of Sig. 0.013 while alpha 0.05 . It can be interpreted that the pre-test and post-test data has a significant relationship. In the output paired sample test, the $t_{\text {count }}$ value was 34.427 while the value of $t_{\text {table }} 1 / 2 \alpha$ was known as 2.201. Thus, the $t_{\text {count }}$ value is much greater than the $t_{\text {table. }}$. It can be concluded that the pre-test data with the post-test has a different average. The Sig. (two tails) is less than alpha $(0.000<0.05)$ means that the difference between pre-test and post-test is significant.

Comparison between post-test scores in group 1 with post-test in group 2 using two different tests on average, with $t$ test or Independent Sample $t_{\text {-test, }}$, obtained data on the value of Sig. In Levene test is larger than alpha $(0.110>0.05)$, then the two data groups have the same variant. The value of $t_{\text {count }}$ is less than $t_{\text {count }}(0.691<2.201)$ then the data has the same average, this is confirmed by the value of Sig. (two tails) is larger than alpha $(0.497>0.05)$ meaning the difference is not significant. It means that both groups have the same average and did not differ significantly, so that it could be said that the use of the microteaching learning model had consistent effect.

Testing the hypothesis about the effectiveness of the research model used a different one average test with $t_{\text {test }}$ or (One Sample $t_{\text {-test }}$ ) obtained an average value of 80.8304 with a standard deviation of 1.97003 , exceeding the estimated average value. The value of $t_{\text {arithmetic }}$ obtained 2.065 while the value of $t_{\text {table }}$ is $1.711\left(t_{\text {table }}=n-1\right.$ 
$(\alpha)=24-1, \alpha \cdot 0.05=1.711)$ thus $t_{\text {count }}$ is larger than $t_{\text {table }}(2.065>1.711)$ so that it could interpret that hypothesis which said that the average mastery skill score of students using the Tadaluring microteaching learning model of 80 was acceptable. This test was corroborated by the findings of the Sig. (2-tailed) 0.055 that larger than alpha (0.05), which means that the tests carried out have a significance value.

There is a number of reasons why the effective Tadaluring teaching-learning models are used, namely the learning experiences in the Tadaluring model greatly contribute significantly to the mastery of various basic teaching skills. The stages in question are the microteaching Tadaluring learning procedure consisting of 5 stages: orientation and training, organizing, observing the learning process and the conditions of the school, teaching practice, and evaluating and following up. All of these stages are carried out continuously, controlled, and intensively by all participants who will take microteaching lectures.

The orientation phase is carried out in order to provide understanding and debriefing to students on the implementation of microteaching learning that will follow. The orientation activity material includes: an explanation of the mechanism of microteaching learning activities (lecture contract), analysis of the ability of microteaching participants in operating various Information Communication and Technology (ICT) media to be used, training in the operation of ICT devices used such as: using cameras, sending and receiving messages via e -mail, download videos from You Tube, communicate via Skype, and edit video footage through the Camtasia studio software. The final activity in the orientation and training period is an explanation of the learning implementation plan, observation sheet, and assessment sheet.

College contracts aim to unite perception and make commitments to the lectures that will be held. In the lecture contract, the supervisor will explain the description of the course, the purpose of the lecture, the form of lectures, the limitations of the assignments or bills of lectures, the form of facilities and infrastructure needed, and the assessment system and indicators.

An analysis of the initial abilities of the microteaching participant students relates to his knowledge of basic teaching skills, ownership of ICT infrastructure that will support learning, and the ability to operate the ICT infrastructure itself. The results of the analysis of the initial capability, ownership of ICT infrastructure, and the ability to operate it will be used as the basis for developing the next strategy, what material must be repeated and the release in what areas should be given. This is an important consideration so that the implementation of learning can run smoothly without being constrained by prerequisite abilities.

Other activities after giving training in using various types of ICT tools are considered weak, discussing the Learning Implementation Plan. Lesson plan is an important learning tool prepared before microteaching learning is carried out. Using the lesson plan, the training process is expected to not deviate from what was planned. The next stage is organizing tasks and arranging the training schedule, this stage consists of activities: setting the structure of group organization, group division, division of tasks between groups, and preparation of presentation schedules for each group. The activity of organizing tasks and preparing the schedule can be carried out 
when discussing lecture contracts at the first meeting.

Organizing tasks and scheduling activities are considered important so that each student or each group understands their respective assignments and can prepare themselves well before they practice both physical preparation, and all the required teaching supplies.

The observation phase of the learning process and school conditions (school observing) is in the next activity. Important school observations are carried out before microteaching learning begins; the activity is carried out so that students of microteaching get a holistic picture of the conditions in the field. It is expected to help students in developing learning strategies in training activities.

The material for school observation activities includes: learning devices (annual programs, semester programs, and lesson plans), learning approaches and curricula used, tools and learning media available, student activities indoor and outdoor, means of learning at schools or institutions, and learning processes inside or outside the classroom. This activity is carried out with the aim that students get to know and obtain an overview of the implementation of the learning process. In observation activities, students do not assess the teacher and do not look for the teacher model, but rather emphasize the effort to know the exemplary figures of the teacher, both regarding mastery of learning material and the appearance of the teacher.

Observation is the life dynamics of the schools or institution to be able to communicate and adapt smoothly and harmoniously. At the end of the observation activity, the students make a summary of the observations and discuss in the group together with the supervisor. The results of these observations were used as enrichment material in the practice of microteaching learning. Instruments that can be used by students in collecting data are observation sheets that have been prepared in advance.

The next step is to look for examples or models of teaching (searching teaching models) that are seen both in the form of videos based on established criteria. Sample search activities are done through You Tube facilities on the internet network. Each microteaching participant student was asked to download a number of videos that aired various examples of basic teaching skills, ranging from opening skills to learning, closing, explaining, managing classes, giving instruction, asking questions, and guiding skills to small group discussions. Through these activities students will share and discuss it.

The activity of finding an example is motivated by the findings of the initial research that in general supervisors in microteaching learning do not provide examples as models that can be replicated or used as guidelines for all participants. So that participants do not know what the right and good basic skills are. Under these conditions students feel difficulty in determining indicators that there should be every form of basic teaching skills. To overcome this problem, it is necessary to have an example (modeling) for participants in the practice that can be obtained through activities searching through the You Tube network.

Search models activities are also based on the opinion of Gredler [11] about social learning theory which has the view that the most important thing is the ability of individuals to extract information from the behavior of others, decide which behavior will be taken, and later to carry out this behavior. According to the theory of social learning, besides learning through direct 
experience a person can also learn something indirectly through observing other people [12].

Videos about teaching activities that have been downloaded by each member in the group, then shared with group members. This file sharing activity is done through a copy process via a flash disk or can also be sent via e-mail. The collected files will then be discussed in their respective groups. The purpose of this activity is for students to get an idea of interesting ways and tricks in training various basic teaching skills.

Videos downloaded from You Tube that present teaching methods can be used as comparative materials and as examples of various activities that are considered interesting in teaching and learning activities. Learning through this example is in accordance with Albert Bandura's social learning theory, which is learning through modeling which consists of four phases, namely the attention phase, the retention phase, the reproductive phase, and the motivational phase.

Understanding the views on social learning theory above can be understood that one can learn well through the imitation process of a model. The researcher believes that observing actions provides space for students to learn the various behaviors displayed in the model. The behavior displayed by someone is studied or modified by paying attention to and imitating the model. Thus microteaching learning can begin with the process of observing various teaching models that are seen as good as an example.

The next activity in microteaching learning is to share and discuss the models that have been obtained. This activity was important in order to evaluate and assess the various learning videos which will be usedlater as references or examples in a practice. The discussion and sharing activities were acceptable with the concept of learning community proposed by Vygotsky. Vygotsky in Nurhadi [13] suggested that learning outcomes could be obtained from collaboration with others. A community of learning could be occurred when there was a two-ways communication process. A person who was involved in the learning community gave information needed by his friend and at the same time asked for information needed from his study partner. Through the sharing and discussion activities, it was expected that students would be able to gain experience and recall various knowledge about various materials related to teaching and learning activities, especially regarding various basic skills in teaching, strategy, methods, media, and evaluation.

The next activity was the practice of microteaching learning. The practice of microteaching learning included: (1) training in preparing lesson plans, (2) exercises in mastering basic teaching skills partially, (3) training in mastering basic teaching skills in an integrated manner, (4) exercise in mastering personality and social competencies. The practice of microteaching learning got the students to have profiles and appearances which reflect the four competencies' mastery, namely: pedagogic, personality, professional, and social.

The lesson plan was done individually by the form of assignment, each student who will practice must prepare lesson plan first. The lesson plan was used when participants showed offin purpose to control the learning process in a practice. The lesson plan was written based on the syllabus which obtained during the school observation.

The practice form of mastering basic teaching skills was carried out in three forms of training, namely classroom practice, online practice, and offline practice. 
Classroom practice was the practice of teaching or practicing basic teaching skills performed in ordinary classrooms equipped by liquid-crystal display (LCD) projectors and portable cameras (mobile phone cameras, digital cameras or camcorders) owned by lecturers or students.

This form of skill which directly and classically trained was the skill of managing the class and the skills of guiding the discussion of small groups. These skills were not easy to train if there were no students near

a trainee teacher, while other basic teaching skills could be performed at different places at the same time.

Online practice is the practice of teaching or practicing basic teaching skills performed in separate places with the same time using Skype communication tools. This online practice can be done at the same time with different places, the timing must be agreed beforehand and the internet network is certainly adequate for video calls. The supervisor and all members can watch the performance and give various comments on the appearance of their group members through their computer screens or smartphone devices.

Offline practice is a teaching practice performed by students who are in the form of assignments but still in one learning unit. Each participant has the duty to perform teaching exercises in their respective places and record them themselves or assisted by colleagues. Each participant must find his or her student in their place of residence or friends of a group. Offline practice in the form of bills or assignments is performed for all forms of basic teaching skills. Each participant is obliged to record 5 times his or her own appearance for each teaching skills trained. The duration for each recording ranges from 5 to 7 minutes. The best recordings according to participants must be posted on the WhatsApp group and asked for comments of the video.

The activity of recording appearance could be performed using recording devices such as hand phone cameras, digital cameras, camcorders, or web cam on the lap top. The recordings could then be edited by yourself using Camtasia studio software. This editing activity was important in order to produce

good recordings, if the participant found parts of the recording that were not interesting or there were certain errors, then the section could

be cut which considered unattractive or wrong, then reconnected with the good ones. In addition to making interesting recordings, students could also make some preliminary or closing displays using the power point software which was then combined with the recording results.

Through the process of editing activities, the students themselves had carried out self-evaluations (self evaluations) as well as changing the way they view of the next performances. By realizing their own mistakes when practicing, they would be able to learn from these mistakes and improve them for the future.

Offline practice activities could increase the frequency of practice and provide the widest opportunity to improve appearance. Recorded duty bills are made every week, each bill would be given online by a supervisor and colleague. Thus participants who practice could find out the weaknesses which were still visible and improving them for next appearance.

The duration and the number of opportunities provided to practice basic skills partially for each participant in classroom practice and online practice was in the range of 5 to 7 minutes, while integrated training 
was available from 20 to 30 minutes. The main activity in microteaching learning was the training process, the amount of practice or practice for each student was at least 6 (six) times in each basic skill and 6 (six) times in an integrated manner by taking into account the level of quality achievement of competencies mastered by students.

Researchers assume that the more opportunities students could practice, the better the mastery of the basic teaching skills which were trained. This view was corroborated by learning theory proposed by Thorndike and his theory of connectionism which was also called trial and error. According to him, learning is the formation of relationships (connections) between the stimulus and the response given by the organism to the stimulus. The typical learning method shown was trial and error (wrong trial).

One of the laws revealed by Thorndike was the law of exercise (law of exercise), which the more frequent the behavior was repeated, trained, and practiced, the association would be stronger. The legal principle of exercise was the connection between conditions (which were stimulants) and the action would be stronger because of the exercises, but would be weaken if the connection between the two was not continued or stopped. The principle of exercise law showed that the main principle in learning was repetition. The more often a skill was repeated, the more skills will be mastered.

Offline practice also provides opportunities for students to control their own way of learning (self-regulated learning). Zimmerman [14] stated that selfregulation is a process whereby a student activates and sustains his cognition, behavior, and feelings which are systematically oriented towards achieving a goal. Self-regulated learning can take place if students systematically direct their behavior and cognizance by paying attention to instructions, assignments, carrying out processes and interpreting knowledge, repeating information to remember and developing and maintaining positive beliefs about learning abilities and being able to anticipate learning outcomes. Thus through the offline practice of microteaching participants will regulate themselves by activating cognitive, affective and behavior so as to achieve learning goals. Each training activity, both directly, online and offline, is carried out by feedback activities.

Feedback activities on student performance were done in two ways, verbally and in writing. Orally done when students had finished practicing each time they practiced. Giving suggestions or comments on student selection was done directly by conveying the privileges that had been maintained and deficiencies which still need to be improved. Giving feedback could be started with recording video playback activities performed by the supervisor or group mates. Students as group members could also provide written responses through the group of WhatsApp group. So giving feedback could be done orally, in writing, and collaboratively between lecturers and students who were standing as participants.

The supervising lecturer could provide feedback based on the recordings submitted by the student through the WhatsApp group by mentioning the form of correction and the minutes and seconds of the occurrence on the recorded results. Each billing video would be given feedback through a scoring form and complemented by a suggestion and criticism column.

The final stage of microteaching learning was evaluation and follow-up. In microteaching learning, assessment activities 
were very crucial. Assessment was needed to determine the extent to which studentteachers had mastered basic skills in teaching. The results of the assessment could be used as information to find out and detect which prospective teachers had been completed and not, which parts of the skills needed to be remedial or improved.

Assessment is a series of activities to obtain, analyze, and interpret data about the process and results of learning achievement [15]. The term evaluation is often associated with terms of measurement and evaluation. Measurement is the process of giving numbers systematically to certain attributes or characteristics. In the measurement process, the phenomenon of the object is transferred into a number so that the teacher can provide relevant meaning [16]. In other words, measurement is the process of comparing something to something or something with a certain size basis. This activity is also a manifestation of the evaluation of the participants' performances.

The final activity of microteaching learning was evaluation. There were two types of evaluation in microteaching learning, called formative evaluation and summative evaluation. Formative evaluation aimed to improve the process of training activities; this was found in the feedback and re-feedback activities. While summative evaluation was the final activity of learning, this was done to determine the extent of the success or mastery of the microteaching participant students to the various basic skills being trained as well as determining the form of follow-up that would be implemented.

Assessment activities in microteaching learning consist of three forms, microplan assessment, practice evaluation both partially and integrated, and assessment of lecture bills. An integrated assessment of teaching skills in microteaching was carried out at the end of several final meetings after students mastered various basic skills in teaching partially.

Following-up of the results of the evaluation could be done through an alternative for participants who got good grades. It could be recommended to the management of prospective teachers II to be placed in superior schools. While for those who did not have a low value, remedial needed to be done. Remedial was done in the form of assignments by increasing bills of practice offline.

Evaluation in microteaching learning was not only done on the ability of participants to master basic teaching skills, but also on evaluation which was performed on all components in the microteaching learning system itself. It started from the components of planning, orientation, school observation, activities to look for models, sharing and discussion activities, practical activities both classical, online, and offline. In addition, evaluation activities were also carried out on the evaluation itself. Thus evaluation must be done holistically on the microteaching learning system.

The Tadaluring microteaching learning model had a number of advantages and weakness as follows (1) Training opportunities could be maximized; each participant had the opportunity to practice a variety of basic teaching skills broadly. Starting from practice in class, practice in network (online), and practice independently (offline), (2) Learning could be carried out anywhere, without requiring a certain room. Practices online and offline provided an opportunity for each participant to carry out learning in the desired place, (3) Providing freedom in practice (self control), time management, material, and carrying out independent evaluations (self evaluation) which were built through independent video 
recording editing processes, (4) Developing social values and independence in learning. Along with its function as teacher, student, and observer in learning activities, each participant needed other people to practice. While learning independence was formed because of the freedom given in various activities.

The weakness of the Tadaluring learning model was as follows. (1) It requires the availability of adequate ICT facilities. The implementing learning online required a number of facilities such as internet networks with speeds above $4 \mathrm{Mbps}$, computer / laptop devices and web cam. While offline practices required technological devices such as HP cameras, camcorders, or digital cameras to record training activities. (2) It requires mastery of specific skills in operating various technological devices used in the learning process. (3) Operational costs were high, especially for the procurement of various ICT infrastructure used.

\section{CONCLUSION}

The study of the effectiveness and practicality of Tadaluring Microteaching Learning Model concludes that the Tadaluring Microteaching learning model is very effective to be used in microteaching learning with the achievement value of the average mastery of various basic skills in teaching was 80.83. The results of hypothesis testing using the one sample $t_{\text {test }}$ showed that the value of $t_{\text {count }} 2.065$ is larger than the value of $\mathrm{t}_{\text {table }} 1.711(\mathrm{t}$ table $=\mathrm{n}-1(\alpha)$ $=24-1, \alpha .0 .05=1.711)$. Therefore, the hypothesis which the average mastery skills of basic teaching skills using the Tadaluring microteaching learning model were acceptable. Sig value. (2-tailed) 0.055 is larger than the value of alpha (0.05), which meant the test had a significant value.

\section{REFERENCES}

[1] M. J. Lakshmi, Microteaching and Prospective Teachers, 4th ed. New Delhi: Discovery Publishing House Pvt. Ltd. Sachin Printers, 2009.

[2] D. W. Allen and A. W. Eve, Microteaching Theory Into Practice. Boston: Taylor \& Francis, Ltd., 1968.

[3] L. C. Singh, Microteaching: An Innovation in Teacher Education. New Delhi: NCERT, 1979.

[4] Moerdianto, Microteaching. Yogyakarta: Universitas Negeri Yogyakarta, 2017.

[5] Arifmiboy, "Teacher Perception on Student Basic Teaching Skill Mastery of Student Teacher Training," 2017.

[6] Arifmiboy, Microteaching. Ponorogo: Wade Group, 2018.

[7] G. A. Brown, Microteaching: Innovation in Teacher Education for Teaching. London: Methuen, 1971.

[8] B. . Passi, Becoming Better Teacher: Microteaching Approach.

Ahmedabad: Sahitya Mudranalaya, 1976.

[9] D. Allen and K. Ryan, Microteaching. California: Addison Wesley Publishing Company Inc., 1969.

[10] S. Singh, "Effective Teaching Competency with Microteaching," Int. J. Educ. Sci. Res., vol. 1, no. 6, pp. 24-32, 2014.

[11] M. E. Bell Gretler, Belajar dan Membelajarkan. Jakarta: PT. Raja Grafindo Persada, 1994.

[12] H. Rahyubi, Teori-teori Belajar dan Aplikasi Pembelajaran Motorik. Bandung: Nusa Media, 2016.

[13] Nurhadi, Pendekatan Konstekstual (Contektual Teaching and Learning CTL). Jakarta: : Departemen Pendidikan Nasional Direktorat Pendidikan Dasar dan Menengah, 2002. 
[14] D. H. Schunk and B. J. Zimmerman, Self-regulation of Learning and Performance: Issues and Educational Applications. Hillsdale: NJ: Erlbaum, 1994.
[15] Suwarna, Pengajaran Mikro. Yogyakarta: Tiara Wacana, 2018.

[16] Sukardi, Evaluasi Pendidikan: Prinsip dan Operasionalnya. Jakarta: Bumi Aksara, 2016. 